\title{
SIPULIN NAATTIHOMEEN TORJUNNASTA.
}

\author{
Risto Arnala \\ Yliopiston kasvipatologinen laitos, Viikin koetila, Helsinki.
}

Saapunut 20, 2. 1951.

Naattihome, jonka aiheuttaa Peronospora destructor BERk., esiintyy sipuleissa kevätnaattihomeena (primaarisena) ja kesänaattihomeena (sekundaarisena)1 ${ }^{1}$ Kevätnaattihome, joka saa alkunsa sairaasta istutusmateriaalista ilmenee kasvukauden alkupuolella. Kevätnaattihomeiset yksilöt jäävät pienikokoisiksi tai kuolevat kokonaan. Kesänaattihometta ilmestyy sipuleihin vasta sitten, kun kevätnaattihomeisten kasvien lehdillä syntyneet taudinaiheuttajan itiöt ovat ilmavirtojen kuljettamina levinneet terveisiin kasveihin ja saastuttaneet ne. Sipulin saastuneissa lehdissä sieni kasvaa nopeasti, tuhoaa solukot ja saavuttaa lopulta itse sipulin, jossa se talvehtii rihmastona (12, p. 607-615, 629).

Sipulissa talvehtivan rihmaston tuhoamiseksi on aikaisemmin kokeiltu sipulin käsittelyä erilaisilla myrkyillä. Tunnetuin on käsittely, jossa sipulit upotetaan 1 tunniksi $1 \%$ formaliiniliuokseen. Formaliinikäsittely on kuitenkin todettu täysin tehottomaksi mm. Maatalouskoelaitoksen kasvitautiosaston kokeissa (9, p. 36).

Nykyisin käytetään naattihomeen rihmaston hävittämiseksi istukassipulin lämpökäsittelyä. Tämä menetelmä onkin varsin käyttökelpoinen, koska naattihomeen rihmasto on osoittautunut lämmön vaikutukselle huomattavasti aremmaksi kuin sipuli. Sipulien lämpötilakäsittely voidaan suorittaa sekä märkäkäsittelynä että kuivakäsittelynä.

Märkälämpökäsittely on yleisesti suositeltu suoritettavaksi siten, että istukassipulit pidetään $1 / 2$ t. $+40^{\circ} \mathrm{C}$ vedessä (vrt. 3, p. 297).

Kuivaa lämpöä sipulin puhdistamiseksi kokeilivat ensimmäisinä MurPHY ja McKAy (7, p. 256). Heidän koetulostensa mukaan sipulin käsittely kuivassa $+40^{\circ} \mathrm{C}$ lämpötilassa $8 \mathrm{t}$. ajan on riittävä tuhoamaan sienen rihmaston tuottamatta vahinkoa sipulille. Lämpötilan noustessa yli $45^{\circ} \mathrm{C}$ sipulit tuhoutuivat. Yarwoodin (12, p. 651) kokeissa jo 4 t. käsittely osoittautui riittäväksi puhdistamaan sipulit naattihomeesta, mutta käsittelylämpötila oli tällöin hieman korkeampi, $41^{\circ} \mathrm{C}$. Myös huomattavan alhainen, $32-35^{\circ} \mathrm{C}$, lämpötila on tehokas sientä vastaan, mutta käsittelyä on tällöin jatkettava verraten kauan, 5-6 vrk. (9, p. 37).

1 Kevät- ja kesänaattihome-nimityksiä on käyttänyt JAmalainen kirjoituksessaan v. 1950 (4). 
Kesänaattihomeen torjuntaan on fungisideja käytetty jo hyvin kauan. Fungisidien vaikutus perustuu siihen, että ne kykenevät jo laimeissakin konsentraatioissa vähentämään tai kokonaan tyrehdyttämään naattihomesienen itiönmuodostuksen ja estävät itiöiden itämisen $(12$, p. 655, 666). Fungisideilla suoritettavaan naattihomeen torjuntaan liittyy kuitenkin melkoisia vaikeuksia. Ehkä suurimman vaikeuden sipulin — samoin kuin eräiden muidenkin kasvien — suojelussa aiheuttaa lehtien nopea kasvu. Lehtien tyvestään kasvaessa lehtitupesta työntyy ruiskutuksen jälkeen esille lehden uusia osia, joihin fungisidin vaikutus ei ole ulottunut (8, p. 18; 12, p. 658). Näissä kohdin saastuminen voi esteettömästi tapahtua, mistä saattaa olla seurauksena myös sairaan kohdan yläpuolella olevien kasvinosien kuoleminen, vaikka ne olisivatkin fungisidin peitossa. Toisen suuren vaikeuden sipulin suojelemisessa aiheuttaa lehtien morfologinen rakenne. Sipulin lehdet ovat sileät ja vahapintaiset, mistä johtuen ruiskutusaine ei lehtiin tartu, ellei ruiskutteisiin lisätä kiinnitysainetta (11, p. 24; 12, p. 660-665). Vaikeutta fungisideilla suoritettavassa naattihomeen torjunnassa lisää sitä paitsi vielä, että ruiskutteet helposti vioittavat sipulin lehtiä, jolloin pahimmissa tapauksissa ruiskutuksista saattaa olla seurauksena suorastaan sadon aleneminen (12, p. $678 ; 6$, p. 80$)$.

Seuraavassa selostetaan Helsingin Yliopiston koetilalla Viikin kartanossa 1948 —49 suoritettuja kokeita, joissa tutkittiin istukassipulin käsittelyn ja naattien fungisidiruiskutuksen vaikutusta sipulihomeen esiintymiseen ja sipulin satoon.

\section{Kokeet Viikin koetilalla vuosina 1948-1949.}

V. 1948 järjestettiin kokeet verraten multavalle urpasavimaalle, jonka ruokamultakerroksen pH oli 5.29-5.48. V. 1949 koealue oli maan laadun puolesta sipulin viljelylle edullisempi. Koealue oli multavaa, hietapitoista urpasavea ja sen muokkauskerroksen $\mathrm{pH}$ oli 5.72-6.14. Lannoituksena annettiin v. $1948300 \mathrm{~kg} / \mathrm{ha}$ superfosfaattia, $200 \mathrm{~kg} /$ ha $40 \%$ kalisuolaa ja $300 \mathrm{~kg} /$ ha kalkkisalpietaria. V. 1949 olivat lannoitemäärät kaksi kertaa suuremmat. Sammutettua kalkkia levitettiin koealalle v. $19494000 \mathrm{~kg} / \mathrm{ha}$. V. 1948 koealuetta ei kalkittu. Sipulien istutus tapahtui v. $194815 / 5$ ja v. $194920-21 / 5$.

Sääsuhteet v. 1948 olivat sipulin kasvulle epäsuotuisat. Toukokuun sademäärä oli suunnilleen normaalinen. Sen sijaan kesä- ja varsinkin heinäkuu olivat erittäin vähäsateisia, jonka johdosta sipulit kärsivät kuivuudesta. Koko kasvukausi oli normaalia jonkin verran lämpimämpi. V. 1949 oli kasvukauden alkupuoli, varsinkin kesäkuu hyvin kostea ja runsassateinen, kun taas heinä- ja elokuun sademäärät olivat normaalista vähän pienemmät. Kasvukauden lämpötila oli lähes normaali.

Kokeissa käytettiin kotimaista istukassipulia, joka oli tavallista kauppatavaraa; sen alkuperää ei tarkemmin tunneta. V. 1948 oli istukassipulien paino keskim. 9 g, v. 1949 keskim. $21 \mathrm{~g}$.

Seuraavia fungisideja käytettiin.

Formaliini. - Formaldehydin $40 \%$ vesiliuos. Istukassipulin käsittelyssä formaliinin käyttölaimennos 1: 100. 
Kasvinsuojelu OY:n kuparikalkki. - Ainetta käytettiin laimennossuhteessa $2: 1.5: 100$.

Rikkikalkkiliuos. - Perusliuoksena oli Kasvinsuojelu OY:n valmiste Rika, jonka väkevyys on $22^{\circ}$ Baume. Käyttölaimennos $1: 30$.

Perenox. - Kuparioksidi-valmiste. Sisältää n. $50 \%$ metallista kuparia. Valmistaja Plant Protection Ltd., Englanti. Käytettiin $0.2 \%$ :na.

Kiinnitysaineina käytettiin:

Kiinnite. - Sisältää hartsisaippuaa. Valmistaja Kasvinsuojelu OY. Lisättiin $1 \%$ ruiskutteeseen.

Valkoöljyemulsio. — Sisältää n. 50 \% valkoöljyä, sekä lisäksi emulgoimisainetta, alkoholia, eräitä neutraloimisaineita ja kostutusainetta. Emulsio oli eräältä kasvinsuojeluliikkeeltä koetarkoituksiin saatu. Emulsiota lisättiin ruiskutteeseen $2 \%$.

Tuhohyönteisten torjunnassa käytettiin:

Hyrgos. - Elohopeakloridi-valmiste. Valmistaja Kasvinsuojelu OY.

Agrocide 3. - Gammeksaani-valmiste. Valmistaja Plant Protection Ltd., Englanti.

Istukassipulin lämpökäsittely suoritettiin v. 194810 —14/5 ja v. 1949 21—29/4. Käsittelyjen aikana lämpötila vaihteli termostaatissa rajoissa $38.5-43^{\circ} \mathrm{C}$. Vesikäsittelyissä lämpötilan vaihtelu oli $39-42^{\circ} \mathrm{C}$. Istukassipulin formaliinikäsittely (1948) suoritettiin $15 / 5$, vähää ennen istutusta.

V. 1948 kokeessa oli ruutujen suuruus $4.0 \mathrm{~m}^{2}$; kerrannaisia oli 8 . V. 1949 koeruutujen suuruus oli $5.2 \mathrm{~m}^{2}$; koesarjassa 1 oli kerrannaisia 5 ja koesarjassa 2 kerrannaisia 6. Koeruutujen etäisyys toisistaan oli $1 \mathrm{~m}$; riviväli oli $30 \mathrm{~cm}$ ja sipulien välimatka $20 \mathrm{~cm}$. - Ruiskutteet levitettiin selkäruiskulla. - Sipulisato korjattiin v. $194821 / 8$ ja v. 1949 31/8-1/9. - Kertausruutujen satojen keskiarvolle laskettiin keskiarvon keskivirhe Zöllerin (10, p. 3) mukaan.

Ensimmäiset kevätnaattihomeen saastuttamat sipulit havaittiin v. $194817 / 6$ ja v. 1949 10/6. Kun lähes kaikki sairaat kasvit kuolivat kokonaan (taulukot $1-3$ ), aiheutti kevätnaattihome siten huomattavan sadon vähennyksen.

Kesänaattihometta ei v. 1948 ilmestynyt. Sen sijaan v. 1949 sitä esiintyi runsaasti. Kesänaattihometta ilmestyi sipuleihin elokuun alkupuoliskolla; 12/8 oli jo suuri joukko kasveja saastunut. Kun naattihomesienen inkubaatıaika on 6-18 pv. (vrt. 1, p. $33 ; 5$, p. 537), tapahtui infektio siis heinä-elokuun vaihteessa.

Tauti levisi hyvin nopeasti. Niinpä sairaita kasveja oli $12 / 820.5 \%$, mutta $30 / 8$ kokonaista $77.3 \%$. Sipulin kukkavarret olivat jonkin verran vastustuskykyisempiä kuin lehdet. Noin kuukauden kuluttua infektiosta (30/8) useita sipulin lehtiä oli jo lähes täydellisesti tuhoutunut, kaikkien kukkavarsien ollessa sitä vastoin vielä pystyssä. Suuret ja rehevät sipulin lehdet saivat tartunnan tavallisesti helpommin kuin pienet.

Kesänaattihomeen esiintymisen ajankohtaan oli kasteen muodostumisella ilmeisesti huomattava osuus. Niinpä alkukesällä, jolloin kastetta oli vähän, infektiota ei tapahtunut, vaikka olosuhteet olivat taudin tartunnalle muuten suotuisat. Kesäkuun lopussa sipulit olivat niin suuria, että kevätnaattihomeisten sipulien homeiset lehdet koskettivat usein terveiden sipulien lehtiä, eivätkä nämä saastuneet. 
Taulukko 1. Istukassipulin formaliinikäsittelyn ja lämpökäsittelyn vaikutus kevätnaattihomeeseen. Istutus 15. 5. 1948 .

Tabelle 1. Die Wirkung von Formalin-und von Wärmebehandlung der Setzzwiebel auf den falschen Mehltau im Frühjahr. Setzen 15. 5. 1948.

\begin{tabular}{|c|c|c|c|c|}
\hline \multirow[t]{3}{*}{ Käsittelyta } & $\begin{array}{l}\text { Istukas- } \\
\text { sipulin } \\
\text { taimistu- } \\
\text { minen }\end{array}$ & $\begin{array}{r}\mathrm{Ke} \\
\text { home }\end{array}$ & $\begin{array}{l}\text { ratti- } \\
\text { rasveja }\end{array}$ & \multirow{3}{*}{$\begin{array}{c}\text { Kevätnaatti } \\
\text { homeisista } \\
\text { kasveista } \\
\text { kuoli } \\
\text { Von den im } \\
\text { Frühjahr } \\
\text { mehltaube- } \\
\text { fallenen } \\
\text { Pflanzen } \\
\text { starben } \\
\%\end{array}$} \\
\hline & $\begin{array}{l}\text { Auflaufen } \\
\text { der Setz- } \\
\text { zwiebel } \\
\%\end{array}$ & \multicolumn{2}{|c|}{$\begin{array}{c}\text { Vom falschen Mehltau } \\
\text { im Frühjahr befallene } \\
\text { Pflanzen } \\
\%\end{array}$} & \\
\hline & $19 / 6$ & $19 / 6$ & $8 / 7$ & \\
\hline Käsittelemätön - Unbehandelt ........... & 91.8 & 25.6 & 26.9 & 97 \\
\hline Formaliini $1 \mathrm{t} . / 1 \%$ - Formalin 1 st $/ 1 \% \ldots \ldots$ & 90.1 & 26.9 & 27.8 & 100 \\
\hline Vesi $1 / 2 \mathrm{t} .+40^{\circ} \mathrm{C}$ - Wasser $1 / 2$ st $+40^{\circ} \mathrm{C} \ldots \ldots$ & 92.3 & 12.8 & 31.3 & 83 \\
\hline Kuiva $24 \mathrm{t} .+40^{\circ} \mathrm{C}-$ Trocken 24 st $+40^{\circ} \mathrm{C} \ldots$ & 90.9 & 0 & 0 & 0 \\
\hline
\end{tabular}

Taulukko 2. Istukassipulin lämpökäsittelyn vaikutus kevätnaattihomeeseen. Istutus 20. 5. 1949, koesarja 1 .

Tabelle 2. Die Wirkung von Wärmebehandlung der Setzzwiebel auf den falschen Mehltau im Frühjahr. Setzen 20. 5. 1949, Versuchsreihe 1.

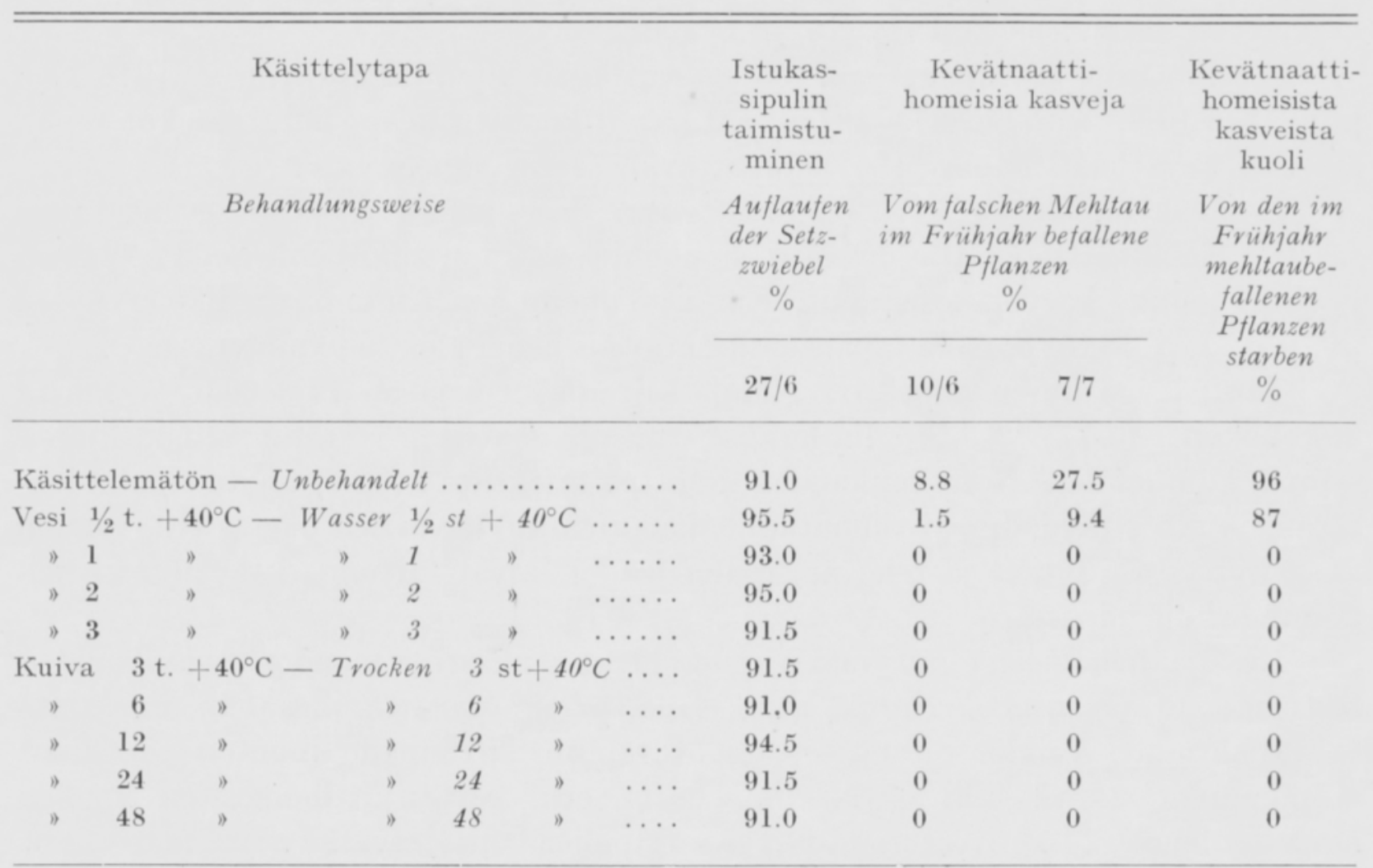


Taulukko 3. Istukassipulin kuivalämpökäsittelyn ja naattien fungisidiruiskutuksen vaikutus kevätnaattihomeeseen. Istutus 21. 5. 1949, koesarja 2.

Tabelle 3. Die Wirkung von Trockenwärmebehandlung der Setzzwiebel und von Fungizidenbespritzung der Blätter auf den falschen Mehltau im Frühjahr. Setzen 21. 5. 1949, Versuchsreihe 2.

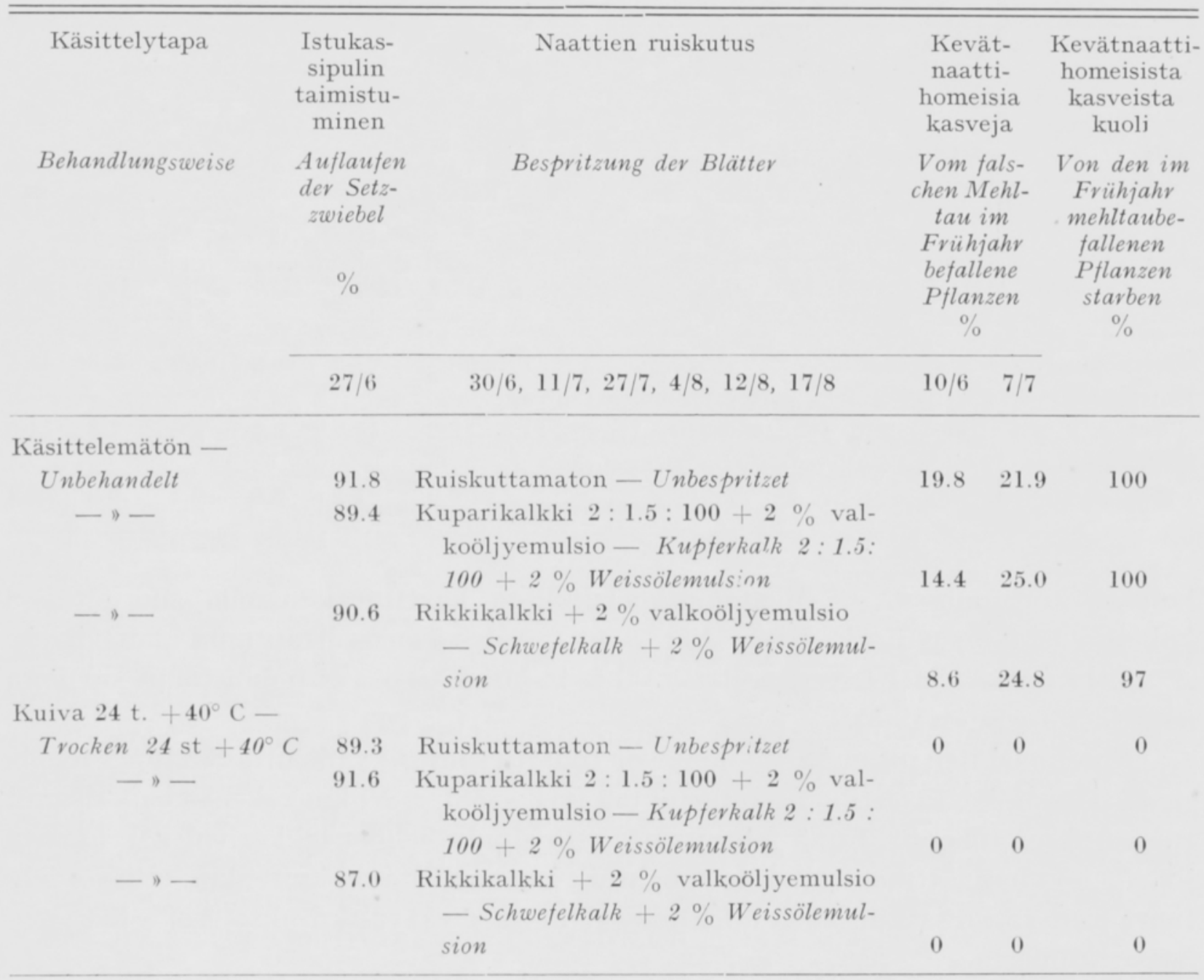

Loppukesällä esiintyi kastetta sen sijaan runsaasti, jonka johdosta olosuhteet muodostuivat erittäin edullisiksi naattihomeinfektiolle. Kaste muodosti yhtenäisen, ohuen vesikerroksen sipulin lehdille, kun taas sadevesi juoksi pisaroina lehtiä myöten alas. Koska infektio on mahdollinen vain silloin, kun lehdillä on nestemäistä vettä (vrt. 1, p. $26 ; 12$, p. 649), tarjosi kaste naattihomeen leviämiselle suotuisan lähtökohdan.

Istukassipulien käsittelyjen vaikutus naattihomesieneen on esitetty taulukoissa $1-3$. Taulukosta 1 ilmenee, että formaliinikäsittely on ollut aivan tehoton naattihometta vastaan. Sen sijaan lämpökäsittely (taulukko 2 sekä 1 ja 3 ) on puhdistanut sipulit naattihomeesta täydellisesti. Niinpä märkäkäsittelyssä jo $1 \mathrm{t} .+40^{\circ} \mathrm{C}$ lämpötilassa oli riittävä, eikä 3 kertaa pitempi (3 t.) käsittelyaika vielä vioittanut sipuleita. Sitä vastoin käsittelyajan ollessa ainoastaan $1 / 2 \mathrm{t}$. sieni ei täysin tuhoutunut. Kuivakäsittelyssä riitti jo $3 \mathrm{t}$. käsittelyaika $+40^{\circ} \mathrm{C}$ lämpötilassa, eikä 16 kertaa pitempiaikainen (48 t.) käsittely ollenkaan vahingoittanut sipuleita. Taulukosta 3 ilmenee samalla, että fungisidiruiskutukset olivat täysin tehottomia kevätnaatti- 
Taulukko 4. Kuparikalkki- ja rikkikalkkiruiskutusten vaikutus kesänaattihomeeseen (1949, koesarja 2).

Tabelle 4. Die Wirkung von Kupferkalk- und Schwefelkalkspritzungen auf den falschen Mehltau im Sommer (1949, Versuchsveihe 2).

\begin{tabular}{|c|c|c|c|c|c|c|}
\hline \multirow{3}{*}{$\begin{array}{l}\text { Naattien ruiskutus } \\
\text { Bespritzung der Blätter } \\
30 / 6,11 / 7,27 / 7,4 / 8,12 / 8,17 / 8\end{array}$} & \multicolumn{6}{|c|}{$\begin{array}{l}\text { Kesänaattihomeisia } \\
\text { Im Sommer von falschem } \\
\text { Mehltaubefallene }\end{array}$} \\
\hline & \multicolumn{2}{|c|}{$\begin{array}{l}\text { Kasveja } \\
\text { Pflanzen } \\
\quad \%\end{array}$} & \multicolumn{2}{|c|}{$\begin{array}{l}\text { Lehtiä } \\
\text { Blätter } \\
\quad \%\end{array}$} & \multicolumn{2}{|c|}{$\begin{array}{c}\text { Kukkavarsia } \\
\text { Blütenstiele } \\
\%\end{array}$} \\
\hline & $12 / 8$ & $30 / 8$ & $12 / 8$ & $30 / 8$ & $12 / 8$ & $30 / 8$ \\
\hline Käsittelemätön - Unbehandelt $\ldots \ldots \ldots \ldots \ldots \ldots \ldots$ & 20.5 & 77.3 & 3.8 & 64.9 & 5.5 & 47.5 \\
\hline $\begin{array}{l}\text { Kuparikalkki } 2: 1.5: 100+2 \% \text { valkoöljyemulsio }- \text { Kup- } \\
\text { ferkalk } 2: 1.5: 100+2 \% \text { Weissölemulsion } \ldots \ldots \ldots \ldots \\
\text { Rikkikalkki }+2 \% \text { valkoölivemulsio }- \text { Schwefelkalk }+\end{array}$ & 2.2 & 17.6 & 0.2 & 4.6 & 1.3 & 11.5 \\
\hline 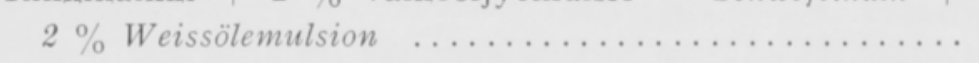 & 0.0 & 1.2 & 0.0 & 0.1 & 0.0 & 0.4 \\
\hline
\end{tabular}

homeen torjunnassa. - Maatalouskoelaitoksen kasvitautiosastolla suoritetuissa kokeissa istukassipulin käsittely $1 / 2 \mathrm{t} .+40^{\circ} \mathrm{C}$ vedessä on osoittautunut liian lyhyeksi, mutta myöskään $1 \mathrm{t}$. vesikäsittely samassa lämpötilassa ei puhdistanut sipuleita naattihomeesta $(4$, p. 5$)$.

Sipulin lehtien pituuskasvu, jonka on todettu suuresti vaikeuttavan fungisideilla suoritettavaa kesänaattihomeen torjuntaa (vrt.s. 68), ei Viikin kokeissa vaikuttanut ruiskutuksen tehoon. Tämä johtui siitä, että sipulin lehdet lakkasivat kasvamasta jo ennen kuin naattihomeinfektio tapahtui. Luonnollista on kuitenkin, että jos lehtien pituuskasvu jatkuu vielä infektion sattuessa, eivät ruiskutukset voi estää sipulia saastumasta.

V. 1948 suoritettiin ruiskutukset 0.2 Perenox $+1 \%$ Kiinnitteellä. Ruiskute tarttui verrattain huonosti, pisaroitui ja juoksi suureksi osaksi lehtiä pitkin alas maahan. Sen sijaan v. 1949 käytetyt ruiskutteet kuparikalkki 2 : 1.5: $100+2 \%$ valkoöljyemulsio ja rikkikalkki $+2 \%$ valkoöljyemulsio tarttuivat hyvin lehtiin ja levisivät niillä tyydyttävästi. Sitä paitsi ruiskutteet eivät sateen vaikutuksesta huuhtoutuneet, joten valkoöljyemulsio osoittautui kiinnittämiskykynsä puolesta erittäin hyväksi.

Kuparikalkki- ja rikkikalkkiruiskutusten vaikutus kesänaattihomeeseen on esitetty taulukossa 4. Siitä ilmenee, että rikkikalkki + valkoöljyemulsio esti hyvin tehokkaasti kasvien saastumisen. Niinpä sipuleista saastui vain $1.2 \%$. Sen sijaan kuparikalkki + valkoöljyemulsion vaikutus oli puutteellisempi; saastuneita kuparikalkki + valkoöljyemulsiolla käsiteltyjä kasveja oli $17.6 \%$. Vastaava luku käsittelemättömillä oli vielä paljon suurempi $(77.3 \%)$.

Havainnot osoittivat, että ruiskutetut sipulien lehdet kostuivat illalla kasteesta hitaammin ja kuivuivat aamulla $2-3$ t. aikaisemmin kuin ruiskuttamattomat. Koska infektiolle välttämätöntä nestemäistä vettä oli täten ruiskutettujen kasvien 
Taulukko 5. Perenox-, kuparikalkki- ja rikkikalkkiruiskutusten aiheuttamat vioitukset.

Tabelle 5. Beschädigungen durch Perenox-, Kupferkalk- und Schwefelkalkspritzungen.

\begin{tabular}{|c|c|c|c|c|c|c|c|}
\hline \multirow{2}{*}{\multicolumn{2}{|c|}{$\begin{array}{l}\text { Naattien ruiskutus } \\
\text { Bespritzung der Blätter }\end{array}$}} & \multirow{2}{*}{\multicolumn{2}{|c|}{$\begin{array}{l}\text { Vioittuneita } \\
\text { kasveja } \\
\text { Beschädigte } \\
\text { Pflanzen }\end{array}$}} & \multicolumn{4}{|c|}{$\begin{array}{l}\text { Vioittumisaste } 0-3^{1} \\
\text { Beschädigungsgrad }\end{array}$} \\
\hline & & & & $\begin{array}{l}\text { Keski. } \\
\text { määrin } \\
\text { Im } \\
\text { Mittel }\end{array}$ & $\begin{array}{l}\text { Raja- } \\
\text { arvot } \\
\text { Grenz- } \\
\text { werte }\end{array}$ & $\begin{array}{l}\text { Keski- } \\
\text { määrin } \\
\text { Im } \\
\text { Mittel }\end{array}$ & $\begin{array}{l}\text { Raja- } \\
\text { arvot } \\
\text { Grenz- } \\
\text { werte }\end{array}$ \\
\hline 1948 & $18 / 6,2 / 7,18 / 7,1 / 8$ & $30 / 6$ & $6 / 8$ & \multicolumn{2}{|c|}{$30 / 6$} & \multicolumn{2}{|c|}{$6 / 8$} \\
\hline \multicolumn{2}{|c|}{$0.2 \%$ Perenox $+1 \%$ Kiinnite } & 20.1 & 33.2 & 0.25 & $0 ?-0.25$ & 0.25 & $0 ?-0.50$ \\
\hline \multicolumn{2}{|c|}{$194930 / 6,11 / 7,27 / 7,4 / 8,12 / 8,17 / 8$} & $25 / 7$ & $22 / 8$ & \multicolumn{2}{|c|}{$25 / 7$} & \multicolumn{2}{|c|}{$22 / 8$} \\
\hline \multirow{2}{*}{\multicolumn{2}{|c|}{$\begin{array}{l}\text { Kuparikalkki } 2: 1.5: 100+2 \% \text { valkoöljyemulsio }- \\
\text { Kupferkalk } 2: 1.5: 100+2 \% \text { Weissölemulsion } \ldots \\
\text { Rikkikalkki }+2 \% \text { valkoöljyemulsio }- \text { Schwefelkalk } \\
\quad+2 \% \text { Weissölemulsion ................... }\end{array}$}} & 9.1 & 38.3 & 0.25 & $0 ?-0.25$ & 0.50 & $0 ?-1.00$ \\
\hline & & 19.9 & 67.4 & 0.50 & $0 ?-0.75$ & 1.000 & $.25-1.50$ \\
\hline
\end{tabular}

lehdillä lyhyemmän ajan, on todennäköistä, että ruiskute jo siten vaikutti ainakin jonkin verran infektiota ehkäisevästi.

Kuten jo edellä (vrt.s. 68) mainittiin, lisää fungisideilla suoritettavassa naattihomeen torjunnassa esiintyviä vaikeuksia myös se, että ruiskutteet helposti vioittavat sipulin lehtiä. Viikin kokeissa ruiskutusten haitallinen vaikutus sipulin naatteihin ilmeni selvästi. Perenox + Kiinnitteen aiheuttamat vioitukset olivat verrattain lieviä. Sen sijaan kuparikalkki + valkoöljyemulsio ja varsinkin rikkikalkki + valkoöljyemulsio vioittivat sipuleita suuresti (taulukko 5).

Ruiskutteiden aiheuttamat vioitukset, jotka alkoivat näkyä tavallisesti jo $3-4$ päivän kuluttua käsittelyn jälkeen, vaihtelivat suuruudeltaan eri käsittelykerroilla huomattavasti. Arimpia fungisidien vaikutukselle sipulin lehdet olivat silloin, kun niiden pituuskasvu oli voimakkainta. Tämä onkin luonnollista, koska lehtien nopeasti kasvaessa solut muodostuvat suuriksi ja ohutkettoisiksi.

Kasvien vioittuminen erityisesti fungisidi + valkoöljyemulsiokäsittelyissä johtui todennäköisesti sekä fungisidista että kiinnitysaineesta. Suurimmat vioitukset aiheutti ehkä fungisidi, mihin viittaa se, että rikkikalkki + valkoöljyemulsiolla ruiskutetut kasvit vahingoittuivat paljon enemmän kuin kuparikalkki + valkoemulsiolla ruiskutetut.

Myös kiinnitysaine, ainakin silloin kun sitä ruiskutteessa on paljon, voi vioittaa sipuleita varsin pahoin. Sitä osoittaa selvästi 12/7 tehty koe, jossa osa lämpökäsittelykokeesta (koesarja 1) ruiskutettiin puhtaalla valkoöljyllä. Öljyn peittämät kas-

$10=$ ei vioitusta keine Beschädigung

$0 ?=$ vioitus erittäin pieni sehr gevinge Beschädigung

3 = kasvi täysin tuhoutunut Pflanze völlig vernichtet 
Taulukko 6. Istukassipulin formaliinikäsittelyn ja lämpökäsittelyn sekä naattien fungisidiruiskutuksen vaikutus sipulisatoon (1948).

Tabelle 6. Die Wirkung von Formalin-und von Wärmebehandlung der Setzzwiebel sowie von Fungizidenbespritzung der Blätter auf den Zwiebelertrag (1948).

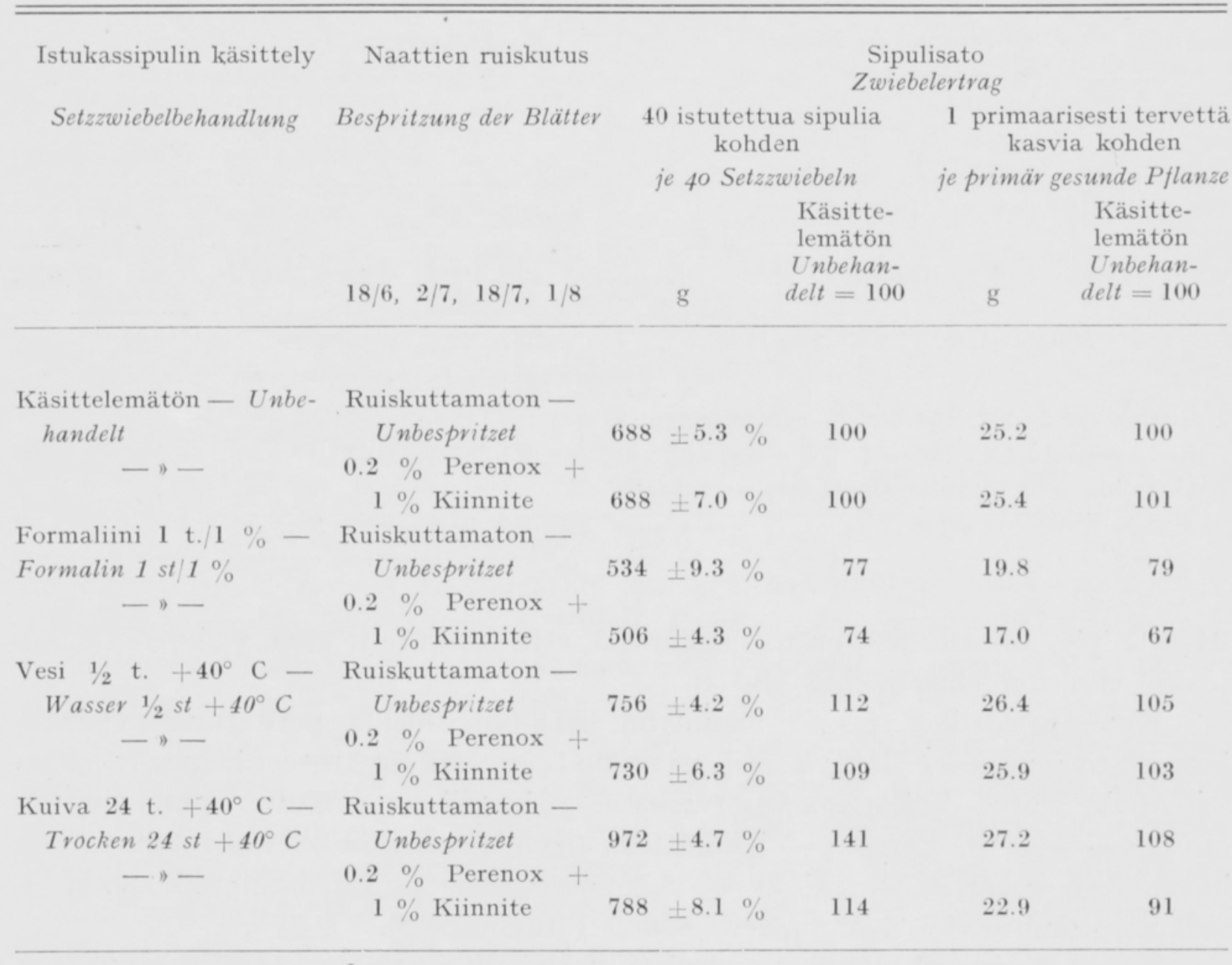

vit vioittuivat ankarasti, vioittumisasteen vaihdellessa $0.50-1.50$. Useita sipulin lehtiä tuhoutui öljyn vaikutuksesta kokonaan. Mistä valkoöljyn haitallinen vaikutus johtui, ei voitu varmuudella sanoa. Kuitenkin todettiin, että öljy tukkesi joko osaksi tai kokonaankin lehtien ilmaraot, joten vioittumista on voinut aiheuttaa mm. hiilidioksidin ja hapen saannin keskeytyminen tai vaikeutuminen.

Kokeiden satotulokset esitetään taulukoissa 6,7 ja 8 . Niistä ilmenee, että istukassipulin märkäkäsittely ja varsinkin kuivakäsittely ovat vaikuttaneet hyvin edullisesti. Pitkäaikaisissa käsittelyissä sadon lisäys on ollut suurin, eräissä tapauksissa jopa yli $70 \%$.

Sekä märkä- että kuivakäsittelyn aiheuttama sadon lisäys johtui pääasiallisesti siitä, että käsittelyllä saatiin hävitetyksi naattihomeen aiheuttaja istukkaista. Kuten taulukoista 7 ja 8 ilmenee, oli kuivakäsittelyllä sitä paitsi välitön sipulin kasvua edistävä vaikutus. Lyhytaikaisilla (3-12 t.) käsittelyillä tämä vaikutus oli vähäinen, mutta pitkäaikaisilla $(24-48$ t.) hyvin selvä. Sen sijaan märkäkäsittelyllä ei ollut mitään varmuudella todettavaa suoranaista vaikutusta sipulin kasvuun. 
Taulukko 7. Istukassipulin lämpökäsittelyn vaikutus sipulisatoon (1949, koesarja 1).

Tabelle 7. Die Wirkung von Wärmebehandlung der Setzzwiebel auf den Zwiebelertrag (1949, Versuchsreihe 1).

Istukassipulin käsittely

Setzzwiebelbehandlung

\section{Sipulisato}

Zwiebelevtrag

40 istutettua sipulia $\quad 1$ primaarisesti tervettä kohden

je 40 Setzzwiebeln

kasvia kohden

je primär gesunde Pflanze

Käsittelemätön Unbehandelt $=$ Unbehandelt =

g

$\begin{array}{rrrrrr}1760 \pm 5.0 & \% & 100 & 66.2 & 100 \\ 1771 \pm 5.5 \% & 101 & 49.5 & 74 \\ 2037 \pm 9.7 \% & 116 & 54.8 & 83 \\ 2739 \pm 6.9 \% & 156 & 72.1 & 109 \\ 2139 \pm 6.3 \% & 121 & 58.4 & 88 \\ 2528 \pm 7.9 \% & 143 & 69.5 & 105 \\ 2561 \pm 7.6 \% & 145 & 70.0 & 106 \\ 2888 \pm 8.3 \% & 164 & 73.8 & 111 \\ 3055 \pm 3.6 \% & 174 & 82.3 & 124 \\ 2943 \pm 5.1 \% & 167 & 80.9 & 122\end{array}$

Formaliinikäsittelyllä oli satoa alentava vaikutus (taulukko 6). Tämä voi ehkä pääasiallisesti johtua siitä, että formaliini on vaikuttanut sipuliin myrkyllisesti, jolloin kasvupiste on voinut vioittua, tai myös käsittelyssä suoritetusta sipulien yläosan poistamisesta, mistä johtuen sipulien vararavintomäärä väheni huomattavasti, varsinkin kun istukassipulit olivat hyvin pieniä.

Kevätnaattihomeen saastuttamien sipulien sato jäi mitättömän vähäiseksi, koska useimmat kevätnaattihomeiset sipulit kuolivat jo kasvukauden keskivaiheilla.

Ruiskutukset vaikuttivat alentavasti sipulisatoon. Verrattaessa taulukkoa 8 taulukkoon 5 ilmenee, että sadon aleneminen on ollut sitä suurempi mitä ankaramman vioituksen ruiskutteet aiheuttivat. Niinpä käsittely rikkikalkki $+2 \%$ valkoöljyemulsiolla, joka oli aiheuttanut suurimmat vauriot sipulille, alensi satoa eniten. Käsittely kuparikalkki $2: 1.5: 100+2 \%$ valkoöljyemulsiolla vähensi myös huomattavasti satoa. Sen sijaan ruiskutus $0.2 \%$ Perenox $+1 \%$ Kiinnitteellä alensi satoa vain hyvin vähän. Elokuun alkupuoliskolla ilmestyneellä kesänaattihomeella ei enää ollut varsin suurta vaikutusta sadon määrään.

Myös Maatalouskoelaitoksen kasvitautiosastolla suoritetut kokeet kesänaattihomeen torjumiseksi ruiskutuksilla ovat antaneet kielteisiä tuloksia (4, p. 6). Ruiskutteet ovat vaikuttaneet haitallisesti naatteihin alentaen satoa. Sen sijaan eräissä muissa sipulin tuotantosuunnissa, kuten sipulin siemenviljelyssä ovat ruiskutukset useimmiten olleet selvästi edullisia (12, p. $675-676 ; 6$, p. 80-82); Viikissäkin suoritetuissa kokeissa kukkavarret sietivät ruiskutusta suhteellisen hyvin.

Kun ruiskutuksiin liittyy suuria vaikeuksia, ennen kaikkea kasvien vioittumisvaara, herää kysymys, eikö fungisidikäsittelyjä voitaisi suorittaa paremmalla me- 
Taulukko 8. Istukassipulin kuivalämpökäsittelyn ja naattien fungisidirıiskutuksen vaikutus sipulisatoon (1949, koesarja 2).

Tabelle 8. Die Wirkung von Trockenwärmebehandlung der Setzzwiebel und von Fungizidenbespritzung der Blätter auf den Zwiebelertrag (1949, Versuchsveihe 2).

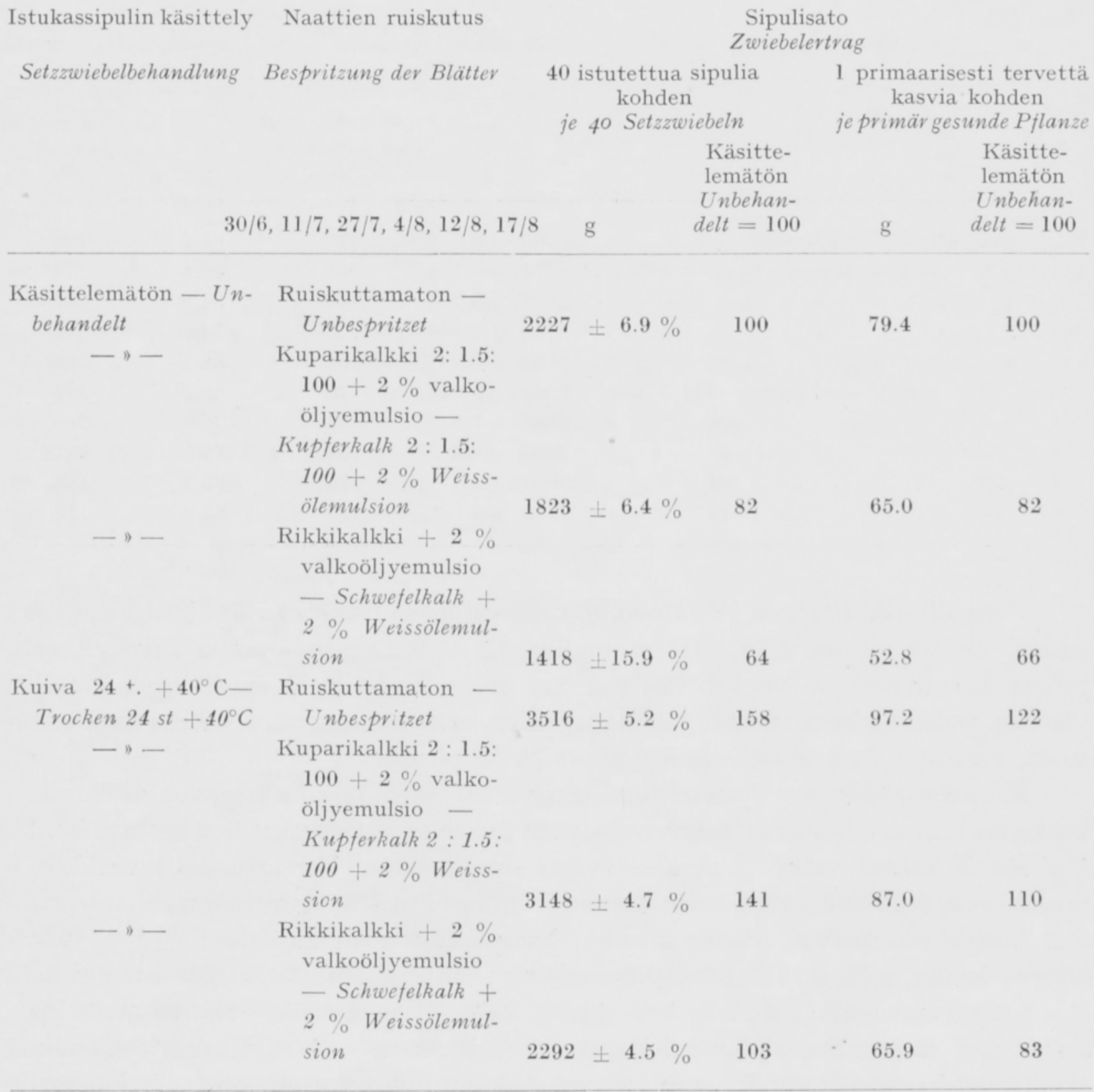

nestyksellä jollakin toisella tavalla. Viikin koetilalla ei tutkittu fungisidien muita käyttötapoja. Sen sijaan ulkomailla on paljon kokeiltu myös sumutusta ja pölytystä. Fungisidisumutus on osoittautunut peltoviljelyksessä suunnilleen fungisidiruiskutuksen arvoiseksi, kun taas pölytykset ovat yleensä olleet lähes täysin tehottomia. Sitä paitsi sumutus ja pölytys voivat vioittaa kasveja aivan yhtä helposti kuin ruiskutus (2, p. $179 ; 12$, p. $665 ; 6$, p. 79). Mikään tähän asti kokeilluista fungisidien käyttötavoista ei siis ole osoittautunut — siemenviljelyksessä saatuja lupaavia tuloksia lukuun ottamatta - edulliseksi sipulin naattihomeen torjunnassa. 


\section{Pä̈telmät.}

Kokeisiin käytetyistä istukassipuleista, jotka olivat tavallista kauppatavaraa, oli lähes $30 \%$ naattihomeen saastuttamia. Niistä kehittyneet kevätnaattihomeiset kasvit yleensä kuolivat sipulisatoa tuottamatta.

Naattihomeen saastuttamista, ennen istutusta lämpökäsitellyistä sipuleista kasvoi täysin terveitä, elinvoimaisia kasveja. Jo 3-tuntinen käsittely kuivassa $+40^{\circ} \mathrm{C}$ lämpötilassa puhdisti istukassipulit naattihomeesta, mutta 16 kertaa pitempikään (48 t.) käsittely ei niitä vioittanut. Myös 1-tuntinen käsittely $+40^{\circ} \mathrm{C}$ vedessä tuhosi naattihomeen, mutta sipulit sietivät vahingoittumattomina ainakin 3 kertaa pitemmän (3 t.) käsittelyajan. Sen sijaan 1/2 t. käsittelyaika osoittautui liian lyhyeksi.

Kuivakäsittelyllä oli sipulin kasvua välittömästi lisäävä vaikutus. Sen ansiosta sato suureni erityisesti pitkäaikaisissa (24 ja 48 t.) käsittelyissä. Sen sijaan märkäkäsittelyllä ei ollut varmuudella todettavaa välitöntä vaikutusta sipulin kasvuun.

Istukassipulien käsittely (1 t.) $1 \%$ formaliiniliuoksessa oli tehoton naattihometta vastaan; sipulien kasvuun se vaikutti haitallisesti.

Kesänaattihome, jota ilmestyi v. 1949 elokuun alkupuolella, tartutti yli $60 \%$ sipulien lehdistä turmellen ne varsin pahoin, mutta sen satoa alentava vaikutus jäi kuitenkin, infektion myöhäisestä ajankohdasta johtuen, verrattain vähäiseksi. V. 1948 ei kesänaattihometta kokeissa esiintynyt.

Maidostuvan valkoöljyn vaikutuksesta fungisidit tarttuivat kasveihin hyvin, jolloin ne suojasivat kasveja tehokkaasti naattihometta vastaan. Tehokkain oli rikkikalkki $+2 \%$ valkoöljyemulsio, kuparikalkki $2: 1.5: 100+2 \%$ valkoöljyemulsion vaikutus oli jonkin verran puutteellisempi. Sen sijaan Perenox $+1 \%$ Kiinnite tarttui verraten huonosti sipulin lehtiin.

Ruiskutteet vioittivat sipulin lehtiä erittäin pahoin. Puhtaalla valkoöljyllä ruiskutetut kasvit vahingoittuivat ankarimmin. Hyvin suuria olivat myös rikkikalkki + valkoöljyemulsion aiheuttamat vauriot. Sen sijaan kuparikalkki + valkoöljyemulsio ja varsinkin Perenox + Kiinnite vahingoittivat sipulin lehtiä huomattavasti vähemmän. Rikkikalkki + valkoöljyemulsioruiskutus, vioittaessaan sipulin lehtiä, vähensi satoa suuresti. Myös kuparikalkki + valkoöljyemulsioruiskutuksella oli huomattava satoa alentava vaikutus, sen sijaan Perenox + Kiinniteruiskutuksella vähäinen.

KIR JALLISUUTTA.

(1) Cook, H. T. 1932. Studies on the downy mildew of onions, and the causal organism, Peronospora destructor (Berk.) Caspary. Cornell University, Agr. Exp. Sta., 143, p. 1-40.

(2) Doran, W. L. ja Bourne, A. J. 1931. Onion Spraying and Dusting Experiments. Massachusetts Agr. Exp. Sta., 279, p. $176-185$.

(3) Gram, E. \& Weber, A. 1944. Plantesygdomme. København.

(4) Jamalainen, E. A. 1950. Sipulin viljely vaikeuksissa. Maatalouskoelaitoksen kasvitautiosaston tiedonantoja, 2, p. 1-11. Moniste.

(5) Jones, H. A., Porter, D. R. \& LeAch, L. D. 1939. Breeding for resistance to onion downy mildew caused by Peronospora destructor. Hilgardia, 12, p. 531-550.

(6) Kristensen, R. ja Jørgensen, M. B. 1948. Bekaempelse af Løgskimmel (Peronospora destructor BERK.) i Frøavl af Kepaløg. Horticultura, 2, p. 77-84. 
(7) Murphy, P. A. ja Mc'Kay, R. 1926. The downy mildew of onions (Peronospora Schleideni) with particular reference to the hibernation of the parasite. The Scientific Proceedings of the Royal Dublin Soc., 18, p. 237-261.

(8) Newhall, A. G. 1939. Progress in control of onion mildew (Peronospora destructor) in New York. Phytopathology, 29, p. 18).

(9) Roivainen, H. 1948. Sipulin viljely entistään paremmaksi. Maatalous, 4, p. $35-37$.

(10) Zöller, W. 1925. Formeln und Tabellen zur Errechnung des mittleren Fehlers. Berlin.

(11) YARwood, C. E. 1939. The Fungicidal Value of Cottonseed Oil and some other Spray Supplements. Phytopathology, 29, p. 24.

(12) —— 1943. Onion downy mildew. Hilgardia, 14, p. 595-691.

\section{R E F E R A T.}

ÜBER DIE BEKÄMPFUNG VOM FALSCHEN MEHLTAU DER ZWIEBEL.

Ristó Arnala

Pflanzenpathologisches Institut der Universität Helsinki, Versuchswirtschaft Viik.

Im pflanzenpathologischen. Institut der Universität Helsinki wurden in den Jahren 1948-1949 Versuche über die Bekämpfung des falschen Mehltaus (Peronospora destructor BERK.) der Zwiebel ausgeführt.

Von den für die Versuche gebrauchten Setzzwiebeln, die gewöhnliche Handelsware waren, waren fast $30 \%$ von falschem Mehltau befallen. Die aus ihnen entwickelten Pflanzen verdarben im allgemeinen, ohne einen Zwiebelertrag hervorzubringen. Aus zwar vom falschen Mehltau befallenen, aber vor dem Auspflanzen wärmebehandelten Zwiebeln wuchsen dagegen ganz gesunde, lebenskräftige Pflanzen auf. Schon eine 3stündige Behandlung in trockener Temperatur von $+40^{\circ} \mathrm{C}$ reinigten die Setzzwiebeln vom falschen Mehltau, aber selbst eine $16 \mathrm{mal}$ so lang andauernde Behandlung (48 st) beschädigte sie nicht. Auch eine lstündige Behandlung im Wasser von $+40^{\circ} \mathrm{C}$ vernichtete den falschen Mehltau, aber die $Z$ wiebeln vertrugen unbeschädigt eine wenigstens 3 mal so lange (3 st) Behandlungszeit. Dagegen erwies sich eine Behandlungszeit von $1 / 2$ st als zu kurz (Tabelle $1-3$ ). Die Trockenbehandlung übte ausserdem einen das Wachstum der Zwiebel unmittelbar steigernden Einfluss aus. Dadurch vergrösserte sich insbesondere bei lang andauernden ( 24 und 48 st) Behandlungen der Ertrag. Dagegen war bei Nassbehandlung ein unmittelbarer Einfluss auf das Wachstum der Zwiebel nicht festzustellen (Tabelle 7). Die Behandlung der Zwiebel (1 st) in 1 \% Formalinlösung war dagegen ohne Wirkung gegen den falschen Mehltau; auf das Wachstum der Zwiebel wirkte sie beeinträchtigend ein (Tabelle 1 und 6).

Der falsche Mehltau, der Anfang August (1949) an den Blättern erschien, befiel über $60 \%$ der Zwiebelblätter (Tabelle 4), sie stark beschädigend, aber seine ertragvermindernde Wirkung blieb infolge des späten Zeitpunktes der Infektion doch verhältnismässig gering. Im Jahre 1948 ist im Sommer kein falscher Mehltau aufgetreten.

Durch emulgierendes Weissöl hafteten die Fungiziden gut an den Pflanzen, wodurch sie die Pflanzen wirksam gegen den falschen Mehltau schützten. Schwefelkalk $+2 \%$ Weissölemulsion war ganz besonders effektiv; Kupferkalk 2 : 1.5 : $100+2 \%$ Weissölemulsion war in der Wirkung etwas weniger gut (Tabelle 4). Perenox + Kiinnite haftete dagegen verhältnismässig schlecht an den $Z$ wiebelblättern.

Die Spritzmittel beschädigten die Zwiebelblätter besonders stark. Die mit reinem Weissöl bespritzten Pflanzen waren am schwersten beschädigt. Sehr gross waren auch die durch Schwefelkalk + Weissölemulsion verursachten Schäden. Dagegen beeinträchtigten Kupferkalk + Weissölemulsion und besonders Perenox + Kiinnite die Zwiebelblätter bedeutend weniger (Tabelle 5). Das Bespritzen mit Schwefelkalk + Weissölemulsion, das die /wiebelblätter beschädigte, verminderte stark den Ertrag. Auch Kupferkalk + Weissölemulsion-Spritzung bewirkte eine erheblichen und Perenox + Kiinnite-Spritzung einen geringen Minderertrag (Tabelle 6 und 8). 